\title{
Educação e Democracia: as lições da Finlândia para o Brasil
}

\author{
Education and Democracy: \\ the learning of Finland in Brazil
}

SAHLBERG, Pasi. Lições Finlandesas 2.0: o que a mudança educacional da Finlândia pode ensinar ao mundo? Tradução de Elena Gaidano. São Paulo: SESISP Editora, 2018. 320 p.

Camila EMÍlIO' Marineide de Oliveira GOMES²

Pasi Sahlberg iniciou sua carreira como professor de matemática e física no ensino básico da Finlândia e exerceu a docência em Universidades. Atualmente é professor de Política Educacional no Instituto Gonski de Educação da Universidade de New South Wales, em Sydney, na Austrália e foi ganhador, com a obra, do Prêmio Grawemeyer, em 2013. O livro resulta de síntese de dez anos de análises políticas e de experiências como professor e gestor educacional, além dos diálogos com milhares de educadores pelo mundo.

Sahlberg conta, nesse livro, como o sistema educacional da Finlândia essencialmente público, em todos os níveis - que era considerado medíocre nos anos 1980, tornou-se um modelo exitoso e motivo de cobiça por outros países, contextualizando as reformas educacionais que abrangeram não apenas o campo da educação, mas a política e a sociedade finlandesa. Ressalta a lentidão das mudanças educacionais com vistas à sua efetividade e a necessidade de tais mudanças envolverem e serem assumidas pelo conjunto da sociedade. No caso da Finlândia isso ocorreu ao longo de três décadas de reformas e ajustes, o que teve como consequência, entre outros aspectos, os resultados positivos

1 Professora de Artes e mestranda do Programa de Pós-Graduação em Educaçáo (PPGE) da Universidade Católica de Santos. E-mail: <camilaemilio@gmail.com>.

2 Doutora em Educaçáo (FE-USP), com pós-doutoramento pela Univ. Católica Portuguesa (Lisboa) e professora do Programa de Pós-Graduação em Educaçáo (PPGE) da Universidade Católica de Santos. E-mail: <neide.ogomes@gmail.com>.

R. Educ. Públ.

Cuiabá

v. 28

n. 67

p. $241-244$

jan./abr. 2019 
nos exames internacionais (aspecto da educação finlandesa que se tornou mais visível para o mundo).

A obra está dividida em breve Introdução, seguida de cinco capítulos. No início, o autor aborda o desafio de preparar os jovens para o mundo do trabalho do futuro, ilustrando com uma expressão alarmante de um ex-presidente da Finlândia de que nos próximos dez anos haverá no mundo cerca de um bilhão de jovens entre 15 e 30 anos sem emprego. No primeiro capítulo, "O sonho Finlandês: uma boa escola para todos", o autor traz um panorama histórico sobre a Finlândia pós-guerra e como ocorreu o processo de reestruturação política, econômica e educacional, importante para o entendimento da situação educacional finlandesa atual em que a associação de professores finlandesa de educação primária teve papel fundamental na criação do sistema educacional público nos anos 1970. No segundo capítulo: 'Paradoxo finlandês: menos é mais', fica evidenciada a estabilidade no ensino finlandês, comprovadamente bem-sucedida, sobretudo pelo uso de estratégias alternativas de desenvolver bons sistemas públicos de educação que diferenciem daqueles oferecidos nos fóruns mundiais de Políticas Educacionais.

O capítulo 3 intitulado: 'A vantagem finlandesa: os professores', se atribui a estes profissionais parcela considerável do êxito alcançado pela educação na Finlândia, demarcando na história da formação dos professores daquele país, um episódio significativo em 1979, no contexto de uma reforma educacional, em que os professores foram desafiados ao uso de métodos instrucionais alternativos e de desenvolverem ambientes de aprendizagem para um ensino diferenciado, aliado à exigência de melhoria na qualificação profissional docente, com o oferecimento de cursos gratuitos de pós-graduação. $\mathrm{O}$ autor ressalta a necessidade de autonomia relativa das escolas em gerir seus projetos educacionais e a importância da confiança nos professores para propor mudanças no cotidiano escolar, elaborar e utilizar alternativas diferenciadas de ensino.

No capítulo 4, 'A via finlandesa: estado competitivo de Bem-estar social', -fica evidenciada a importância do grau de desenvolvimento em outras áreas setoriais para haver sucesso no sistema educacional, com bons índices em áreas como comércio, tecnologia, igualdade de gênero, bem-estar infantil, boa governança e sobretudo, uma adequada estrutura de saúde e emprego para todos. O último capítulo traz uma pergunta: 'O futuro, é finlandês?' Nele o autor reafirma alguns pontos positivos do ensino na Finlândia, discutidos no livro, com ênfase ao que considera ser o fundamental no trabalho dos professores: ajudar as crianças a aprender e prestar atenção nas suas necessidades, o que se apresenta como sentido do trabalho docente. Dentre as propostas do autor para se atingir a excelência de ensino, a mais valiosa de todas, é que uma educação democrática só acontecerá em um país consolidado democraticamente. 
A profissão docente (em sua maioria exercida por mulheres) é hoje a mais concorrida do país. O desejo pela profissão na Finlândia chega a 98\% dos estudantes aptos a concorrerem à vaga. Os salários dos professores finlandeses são equiparados aos salários de outras profissôes prestigiadas, sendo que o fator que atrai os jovens professores é a autonomia profissional, vez que boa parte dos professores finlandeses desistiria da profissão, caso precisasse cumprir metas estabelecidas por avaliaçóes e exames externos. A construção social e as imagens interna e externa da profissão docente contribuem assim para gerar uma motivação crescente nos professores.

O tempo diário de aula dos estudantes e dos professores finlandeses é inferior à média dos países que estão no topo das avaliaçóes internacionais (média de 20 horas semanais), o que contraria a ideia de que um tempo maior de estudantes e professores na escola representa maior aprendizagem dos estudantes. Das áreas curriculares há a prioridade para a leitura e a escrita com reflexos sociais: a populaçáo finlandesa lê assiduamente, sendo que dois de cada três adultos na Finlândia são bons ou excelentes leitores.

Com a política educacional finlandesa de prioridade à educação e de valorização de professores, a Finlândia caminha em sentido contrário às Políticas Educacionais globais pois não existe concorrência entre as escolas, nem há padronização da educação, as prestaçóes de contas não se pautam pelos testes em larga escala e o foco em disciplinas essenciais do currículo não subestima as demais áreas do conhecimento. A valorização profissional dos professores levouos à criação de políticas alternativas de estímulo das crianças e jovens visando um desenvolvimento humano e integral. $\mathrm{O}$ sucesso nos testes padronizados internacionais resulta de consequência natural do sucesso de Políticas Públicas Educacionais que priorizam a educação pública e é alimentado pelos diferentes atores educacionais e pela sociedade que têm a educação como valor.

$\mathrm{O}$ autor discute a função social da educação básica em um país democrático que ao longo de três décadas construiu socialmente um pacto pela educação pública, com uma perspectiva integrada e sistêmica, pela valorização e promoção da autonomia das escolas e dos professores, de modo a formar o estudante para os desafios da vida, de forma global e articulada.

Em relaçáo ao baixo desempenho educacional do Brasil (ocupando a 60a posição - dentre 76 países, na avaliação do teste Pisa, realizada em 2015), escolhemos ir ao ponto que julgamos fundamental para que a educação entre nós alce patamares dignos e que seja reveladora de reais aprendizagens para todos os envolvidos nos processos educacionais e que é reforçado pelo autor: a necessidade de democracias consolidadas para o êxito educacional, exercida por uma boa governança política em todas as esferas, entendida a educação como 
bem público. Tal condição, ao nosso ver, se configura como peça-chave para a compreensão do sistema educacional brasileiro em que as disputas históricas entre o público-privado se intensificam, sempre que os privilégios das grandes corporaçóes se veem ameaçadas. Ao mesmo tempo as 'lições da Finlândia' lançam luzes sobre possibilidades de melhoria na educação que temos, se considerarmos a apropriação pela sociedade das Políticas Educacionais por meio do conceito de governança pública, pautado nos princípios do controle do Estado (interno e externo) e da sociedade, pelo estímulo à transparência, à equidade, à justiça e à accountability (prestação de contas com responsabilidade pública).

No Brasil, país de profundas desigualdades sociais que se polariza entre as carências e os privilégios, o campo da Educação tem pouco a avançar se as condiçóes básicas de vida da população, em geral, não evoluir, se a profissão docente não conquistar outro status de reconhecimento social (o que náo se faz da noite para o dia), se a educação não for entendida como processo e não medida somente por resultados de avaliações externas, que não dialogam com a realidade das escolas e dos professores e se não for enfrentado o cartel dos grandes grupos econômicos financistas que pautam as Políticas Públicas Educacionais e ameaçam o direito à educação (entre outros aspectos). No que se refere à consolidaçáo democrática, as ameaças à democracia no país se fazem presentes ao longo da nossa história (do processo de colonização do país aos dias atuais). Os avanços sociais observados nas últimas décadas náo estão consolidados, ao contrário, as características básicas da sociedade brasileira calcadas no patrimonialismo e no clientelismo continuam a reforçar a tutela e o favor nas relaçóes entre Estado, governo e sociedade e prestam um des-serviço na perspectiva da educação como direito.

Das 'lições da Finlândia', o dever de casa da educação pública no Brasil - fruto de processo democrático - ainda está por ser feito... 